\title{
Is the TSHR D727E polymorphism a genetic predisposition for multinodular goiter in the Turkish population?
}

\author{
H.I. Gözü̈ ${ }^{1}$, S. Özçelik², M. Aloğlu ${ }^{3}$, A. Şahin ${ }^{3}$, S. Temiz ${ }^{2}$, A. Dayan², \\ H. Cengiz ${ }^{2}$, Y. Tütüncü̈ ${ }^{2}$ and R. Bircan ${ }^{4}$ \\ ${ }^{1}$ Department of Endocrinology and Metabolism, School of Medicine, \\ Marmara University, Istanbul, Turkey \\ ${ }^{2}$ Endocrinology and Metabolism Section, Haydarpaşa Education Hospital, \\ Istanbul, Turkey \\ ${ }^{3}$ Internal Medicine Section, Haydarpaşa Education Hospital, Istanbul, Turkey \\ ${ }^{4}$ Division of Biology, Department of Molecular Biology and Genetics, \\ Faculty of Arts and Sciences, Namık Kemal University, Tekirdag, Turkey \\ Corresponding author: R. Bircan \\ E-mail: rifatbircan@yahoo.com
}

Genet. Mol. Res. 15 (3): gmr.15038504

Received January 27, 2016

Accepted March 11, 2016

Published August 5, 2016

DOI http://dx.doi.org/10.4238/gmr.15038504

Copyright (C) 2016 The Authors. This is an open-access article distributed under the terms of the Creative Commons Attribution ShareAlike (CC BY-SA) 4.0 License.

ABSTRACT. The D727E germline polymorphism in the thyroid-
stimulating hormone receptor gene (TSHR) may cause genetic
susceptibility to the development of goiter. Therefore, in this study we
investigated allele frequencies and genotype distributions of the TSHR
D727E polymorphism, their association with clinical parameters, and
the development of goiter in the Turkish population. We investigated
the TSHR D727E polymorphism in 123 patients and 97 healthy
subjects using the polymerase chain reaction-restriction fragment
length polymorphism technique. Peripheral blood was used for DNA 
extraction. Although no significant difference was found in TSHR D727E polymorphism frequencies between the patients with nodular goiters $(26 / 123$ patients, $21.1 \%)$ and the controls (12/97 patients, $12.4 \%)(\mathrm{P}=0.107)$, the frequency of the TSHR $\mathrm{D} 727 \mathrm{E}$ polymorphism in the hyperthyroid+subclinical hyperthyroid patient groups $(23 \%)$ was significantly higher than in the control subjects $(12.4 \%)(\mathrm{P}=0.024)$. In this study, nodular goiter presented significantly earlier in GC genotype patients (mean age 35 years) than in CC genotype patients (mean age 42 years $)$ in the hyperthyroid group $(\mathrm{P}=0.009)$. More importantly, TSH levels in the $\mathrm{GC}$ variant controls were closely significant lower (1.26 $\pm 0.49)$ than in the $\mathrm{CC}$ variant controls $(1.74 \pm 0.84)(\mathrm{P}=0.053)$. The TSHR D727E polymorphism might be involved in the pathogenesis of toxic multinodular goiter (TMNG). Moreover, this polymorphism might be an indication of early-onset TMNG. However, development of MNG is multifactorial. Therefore, further case-control studies with larger populations are required to verify these observations.

Key words: Thyroid; Toxic MNG; TSHR D727E; Polymorphism

\section{INTRODUCTION}

A goiter, which is described as any enlargement of the thyroid tissue, is an important and continuing health problem globally. Whether diffuse or nodular, its prevalence ranges from 5 to $50 \%$, although that figure varies depending on the detection method used as well as the population studied. In nodular goiters, the prevalence is higher in women in areas of iodine deficiency, and increases with advancing age (Bahn and Castro, 2011).

Family and twin pair studies in endemic and non-endemic areas have clearly demonstrated a genetic predisposition for goiter development (Brix et al., 1999; Krohn et al., 2005). In endemic regions, genetic factors play a secondary role in the etiology of goiter in contrast to non-endemic regions in which genetic factors play a major etiologic role (Greig et al., 1967; Malamos et al., 1967; Brix et al., 1999). In non-endemic regions, approximately $82 \%$ of clinically overt simple goiters are attributable to genetic factors, whereas environmental factors explain the remaining 18\% (Brix et al., 1999). Indeed, it has been proven that goiter is a result of interactions between both primary (genetic) and secondary (environmental) factors. The widely accepted risk factors such as iodine deficiency, smoking, old age, and female gender are likely to interact with and/or trigger genetic susceptibility (Brix et al., 1999; Krohn et al., 2005).

One of the candidate genetic risk factors for the development of thyroid diseases is thyroidstimulating hormone receptor (TSHR), which is a member of the large family of G protein-coupled receptors according to its central role in thyroid function and growth (Paschke and Ludgate, 1997; Porcellini et al., 1997; Gozu et al., 2009). Somatic mutations in the signal transduction pathway (TSHR or GNAS) constitutively activate the cAMP cascade, and result in growth and hyperfunction of the thyroid follicular cells and ultimately thyroid autonomy. The frequency of somatic TSHR mutations in toxic thyroid nodules varies between 8 and $82 \%$ (Gozu et al., 2006).

In contrast to somatic mutations, polymorphisms may have little effect on the function of proteins, and do not necessarily cause overtly debilitating diseases. Only three germline TSHR polymorphisms, resulting in amino acid exchange, have been identified (Duprez et al.,

Genetics and Molecular Research 15 (3): gmr.15038504 
1998): two are located in the extracellular portion of the receptor (D36H and P52T); and the third is described as a substitution of glutamic acid for aspartic acid (D727E), and is located within the intracellular portion of TSHR (Tonacchera and Pinchera, 2000).

The TSHR D727E variant is not constitutively activating in the manner of the previously reported mutations found in toxic multinodular goiter (TMNG). In vitro studies have shown that basal cAMP generation is not altered in cells expressing TSHR with polymorphic D727E compared with wild-type cells. However, the D727E variant receptor has a higher sensitivity compared with the wild-type receptor, indicating that it does exhibit somewhat altered biological behavior because less TSH is needed to produce normal free thyroxine (fT4) levels (Gabriel et al., 1999).

The results obtained from case-control studies regarding the possible association of the TSHR D727E polymorphism and multinodular goiter (MNG) and TMNG in different populations are inconsistent (Gabriel et al., 1999; Mühlberg et al., 2000; Sykiotis et al., 2003; Hansen et al., 2007; Tug et al., 2012; Bayram et al., 2013).

The present study, therefore, aimed to determine the allele frequencies and genotype distributions of the TSHR gene D727E polymorphism and its association with iodine status, clinical parameters, and the development of goiter in the Turkish population.

\section{MATERIAL AND METHODS}

A total of 123 patients and 97 healthy controls without evidence of thyroid disorders who had been admitted to our endocrinology clinics were enrolled in this study. All the patients gave written informed consent, and the study was approved by the Ethics Committee at each participating institution. The patients examined (mean age $47.57 \pm 12.55$; range 20-75 years) had undergone thyroidectomy for toxic or non-toxic multinodular goiter. Demographical and clinical data, such as personal and family history, age, smoking habits, and age at disease onset, were recorded. The patient's place of birth and habitation in Turkey were also logged. In this study, iodine-deficient, sufficient, and mixed regions were identified, as described in a previous study (Gozu et al., 2006). In these patients, thyroid function was tested [total or free triiodothyronine (T3), T4, and TSH], and thyroid peroxidase antibodies (anti-TPO) were measured. Investigations were also carried out using thyroid ultrasonography and ${ }^{99 \mathrm{~m}} \mathrm{Tc}$ scintigraphy. Accordingly, the patients were classified as euthyroid, hyperthyroid, or subclinical hyperthyroid with normal free T3 (fT3) and fT4 levels, and TSH values lower than $0.1 \mu \mathrm{IU} / \mathrm{mL}$ (Biondi et al., 2005). In addition, all surgical thyroid specimens were histologically examined for the occurrence of inflammatory cell infiltration. Patients were excluded if anti-thyroid peroxidase (anti-TPO) antibodies were positive and/or lymphocytic thyroiditis diagnosed by pathology was present.

The diagnosis of MNG or TMNG was based on clinical and biochemical data, and was confirmed by histological examination. All healthy control participants had documented normal thyroid function and had no evidence of thyroid autoimmune or non-autoimmune disease, as determined by a careful investigation of personal and family history, clinical examination, thyroid function testing, thyroid autoantibody testing, and thyroid ultrasound testing.

\section{Genetic analysis of TSHR D727E polymorphism}

Genomic DNA was extracted from peripheral blood mononuclear cells using a standard phenol-chloroform methodology. To investigate the TSHR D727E polymorphism in exon 10 of

Genetics and Molecular Research 15 (3): gmr.15038504 
the TSHR gene, a polymerase chain reaction(PCR) was performed, as described previously (Gozu et al., 2006). PCR amplification was performed in a final volume of $50 \mu \mathrm{L}$ containing $10 \mathrm{pmol}$ each of the appropriate primers [TSHRF (forward) 5'-GTCAGCAATTCTGAACAAGCC-3' and TSHRR (reverse) 5'-TTCTTTGGGGTTAGATGGG-3'], $200 \mu \mathrm{M}$ dNTPs, $1.5 \mathrm{mM} \mathrm{MgCl}$, $1 \mathrm{U}$ Taq polymerase, $10 \mathrm{X}$ reaction buffer $\left[500 \mathrm{mM}\right.$ Tris- $\mathrm{HCl}, \mathrm{pH} 8.8,160 \mathrm{mM}\left(\mathrm{NH}_{4}\right) \mathrm{SO}_{4}$, and $0.1 \%$ Tween $^{\circledR} 20$ ] (MBI Fermantas, Lithuania), and 100 ng DNA. The PCR protocol comprised an initial denaturation at $94^{\circ} \mathrm{C}$ for $3 \mathrm{~min}$, thereafter denaturation at $94^{\circ} \mathrm{C}$, annealing at $60^{\circ} \mathrm{C}$, and extension at $72^{\circ} \mathrm{C}$ for $30 \mathrm{~s}$ each, for 35 cycles, with a final $10 \mathrm{~min}$ extension at $72^{\circ} \mathrm{C}$. The obtained $327-\mathrm{bp}$ PCR products were separated on $2 \%$ agarose gel, stained with ethidium bromide, and visualized by UV transillumination. Afterwards, $10 \mu \mathrm{L}$ amplification products was digested with $5 \mathrm{U}$ Hsp92II restriction enzyme (Promega, USA) for $4 \mathrm{~h}$ at $37^{\circ} \mathrm{C}$ and separated on $2.5 \%$ agarose gel, stained with ethidium bromide, and visualized by UV transillumination, as described previously (Mühlberg et al., 2000). The PCR products with the CC (TSHR 727D) genotype yielded 255-, 51-, and 21-bp DNA fragments, whereas the products with the GG (TSHR D727E) genotype yielded 276- and 51-bp fragments, and the PCR products with the CG (TSHR D727E) genotype yielded 276-, 255-, 51-, and 21-bp fragments.

\section{Statistics}

The Number Cruncher Statistical System (2007, NCSS, LLC, Kaysville, UT, USA) software was used for the statistical analyses. The data were evaluated using descriptive statistical methods such as mean, standard deviation, median, frequency, and percentage. Oneway analysis of variance (ANOVA) was used for comparisons of normally distributed variables, while the Student $t$-test was used for two-group comparisons. The Mann-Whitney U-test was used for comparisons where the variables were not normally distributed. To compare qualitative data, the Pearson chi-square test, the Yates' continuity correction, and the Fischer exact test were used. The results were evaluated with $95 \%$ CIs and $\mathrm{P}$ values $<0.05$ were considered significant.

\section{RESULTS}

\section{Demographic parameters of the patients and control subjects}

A case-control study was conducted in a group of 123 patients with MNG and in 97 ageand sex-matched healthy control subjects. The mean age of the patients was $47.57 \pm 12.55$ years, and $104(84.6 \%)$ patients were women. Healthy subjects were of mean age $45.91 \pm 14.97$ years, with a female percentage of $75.3 \%$. Table 1 shows the demographic parameters of the study group.

\begin{tabular}{|c|c|c|c|c|}
\hline & & Patients (N: 123) means $\pm \mathrm{SD}$ & Controls (N: 97) means \pm SD & $\mathrm{P}$ value \\
\hline Age (years) means \pm SD & & $47.57 \pm 12.55$ & $45.91 \pm 14.97$ & $0.381^{\mathrm{a}}$ \\
\hline \multirow[t]{2}{*}{ Gender [N (\%)] } & Female & $104(84.6 \%)$ & $73(75.3 \%)$ & \multirow[t]{2}{*}{$0.084^{\mathrm{b}}$} \\
\hline & Male & $19(15.4 \%)$ & $24(24.7 \%)$ & \\
\hline \multirow[t]{3}{*}{ Iodine status [N (\%)] } & Iodine-deficient & $39(31.7 \%)$ & $4(4.1 \%)$ & \multirow[t]{3}{*}{$0.001^{\mathrm{b}}$} \\
\hline & Iodine-sufficient & $20(16.3 \%)$ & $17(17.5)$ & \\
\hline & Mixed & $64(52.0 \%)$ & $76(78.4 \%)$ & \\
\hline Smoking [N (\%)] & & $22(17.9 \%)$ & $27(27.8 \%)$ & $0.110^{\mathrm{c}}$ \\
\hline Family history (FH) [N (\%)] & & $46(38 \%)$ & $22(22.7 \%)$ & $0.015^{\mathrm{b}}$ \\
\hline \multirow[t]{2}{*}{ Age at disease onset } & FH (present) & $36.58 \pm 11.83$ & & \multirow[t]{2}{*}{$0.036^{\mathrm{a}}$} \\
\hline & FH (absent) & $41.48 \pm 12.17$ & & \\
\hline
\end{tabular}

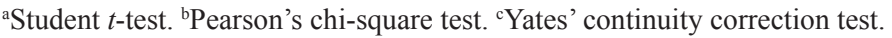

Genetics and Molecular Research 15 (3): gmr.15038504 
The prevalence of patients from iodine-deficient regions were significantly higher than the controls ( 31.7 vs $4.1 \% ; \mathrm{P}=0.001)$. Corresponding to socioeconomic status, the number of smokers was higher in the control group than in the patient group, but the difference was not significant (17.9 vs 27.8\%; $\mathrm{P}=0.110)$. In contrast to smoking habit as a risk factor, prevalence of family history in the patient group was significantly higher than in the controls (38 vs $22.7 \% ; \mathrm{P}=0.015$; Table 1 ).

\section{Prevalence of TSHR D727E polymorphism and its correlation with demographic and clinical parameters}

Two genotypes, GG and GC, at locus 727 of the TSHR gene were detected in 26 of 123 unrelated individuals $(21.1 \%)$ by restriction enzyme digestion screening. There were no statistically significant differences in codon 727 polymorphism frequencies between the patients with multinodular goiter $(21.1 \%)$ and the healthy controls $(12.4 \%) ;(\mathrm{P}=0.107$; Table 2$)$.

Table 2. Prevalence of TSHR D727E polymorphism in patients and controls.

\begin{tabular}{l|c|c|c|c|c|c}
\hline & \multicolumn{3}{|c|}{ TSHR D727E genotype } & \multicolumn{2}{c}{ Allele frequency } & P value \\
\cline { 2 - 7 } & CC & CG & GG & C & $0.107^{\text {a }}$ \\
\hline Patients N (\%) & $97(78.9 \%)$ & $24(19.5 \%)$ & $2(1.6 \%)$ & 0.886 & 0.114 \\
\hline Controls N (\%) & $85(87.6 \%)$ & $12(12.4 \%)$ & $0(0 \%)$ & 0.938 & 0.062 \\
\hline
\end{tabular}

aPearson's chi-square test.

However, the frequency of the TSHR D727E polymorphism (GC+GG genotype) in the hyperthyroid+subclinical hyperthyroid group $(23 \%)$ was significantly higher than in the other groups including the euthyroid patients $(9.1 \%)$ and the healthy controls $(12.4 \%)(\mathrm{P}=$ 0.024) when all groups were compared. Remarkably, the frequency of the TSHR D727E wildtype allele (CC genotype) in the euthyroid patients seemed almost the same as in the control groups (90 vs 87.6\%; Table 3).

Table 3. Distribution and comparison of the TSHR D727E polymorphism among the groups.

\begin{tabular}{l|c|c|c}
\hline Distribution between groups & TSHR D727E CC (N:182) N (\%) & TSHR D727E GC+GG (N:38) N (\%) & P value \\
\hline Hyperthyroid+subclinical hyperthyroid* & $67(67 \%)$ & $23(23 \%)$ & $0.024^{\mathrm{a}}$ \\
\hline Euthyroid & $30(90.9 \%)$ & $3(9.1 \%)$ & $12(12.4 \%)$ \\
\hline Control & $85(87.6 \%)$ & & \\
\hline Comparison between groups & & & $0.048^{\mathrm{a}}$ \\
\hline $\begin{array}{l}\text { Hyperthyroid+subclinical } \\
\text { Hyperthyroid+euthyroid }\end{array}$ & & & $0.034^{\mathrm{a}}$ \\
\hline $\begin{array}{l}\text { Hyperthyroid+subclinical } \\
\text { Hyperthyroid+control }\end{array}$ & & & \\
\hline
\end{tabular}
Hyperthyroid+control

*Hyperthyroid and subclinical hyperthyroid patient groups were considered as one group owing to insufficient numbers of subclinical hyperthyroid patients (12 patients) for statistical analysis. ${ }^{\text {a } Y a t e s ' ~ c o n t i n u i t y ~ c o r r e c t i o n ~ t e s t . ~}$

When the prevalence of the TSHR D727E polymorphism was compared between patient subgroups, a statistically significant difference was found between hyperthyroid+subclinical hyperthyroid and euthyroid patient subgroups $(\mathrm{P}=0.048)$. Also, statistical power was much higher in the hyperthyroid+subclinical hyperthyroid patients and control subjects compared with the other groups $(\mathrm{P}=0.034$; Table 3$)$.

There were no statistically significant differences between the distribution of the TSHR polymorphism with age and gender between patients and controls (age of patients and

Genetics and Molecular Research 15 (3): gmr.15038504 
controls: $\mathrm{P}=0.520$ and $\mathrm{P}=0.917$, respectively; gender of patients and controls: $\mathrm{P}=0.572$ and $\mathrm{P}=0.744$, respectively; data not shown in tables). No correlation was found between the TSHR D727E polymorphism and family history, smoking habit, and iodine status in the patients $(\mathrm{P}=0.233,0.564$, and 0.977 , respectively; Table 4$)$.

\begin{tabular}{|c|c|c|c|c|}
\hline & & TSHR D727E CC $(\mathrm{N}=97)[\mathrm{N}(\%)]$ & TSHR D727EGC+GG $(\mathrm{N}=26)[\mathrm{N}(\%)]$ & $P$ value \\
\hline \multirow{2}{*}{ Smoking habit } & Smokers & $16(16.5 \%)$ & $6(23.1 \%)$ & \multirow[t]{2}{*}{$0.564^{\mathrm{a}}$} \\
\hline & Non-smokers & $81(83.5 \%)$ & $20(76.9 \%)$ & \\
\hline \multirow[t]{3}{*}{ Iodine status } & Deficient & $31(32 \%)$ & $8(30.8 \%)$ & \multirow[t]{3}{*}{$0.977^{\mathrm{b}}$} \\
\hline & Sufficient & $16(16.5 \%)$ & $4(15.4 \%)$ & \\
\hline & Mixed & $50(51.5 \%)$ & $14(53.8 \%)$ & \\
\hline \multirow[t]{2}{*}{ Family history } & Present & $33(34.7 \%)$ & $13(50 \%)$ & $0.233^{\mathrm{c}}$ \\
\hline & Absent & $62(65.3 \%)$ & $13(50 \%)$ & \\
\hline
\end{tabular}

${ }^{\mathrm{a}}$ Fisher exact test. ${ }^{\mathrm{b}}$ Pearson's chi-square test. 'Yates' continuity correction test.

For those patients that carried the TSHR GC variant, the development of MNG began early in life, but it was not statistically significant $(\mathrm{P}=0.107)$ (data not shown in tables). In contrast, in the hyperthyroid group, age at disease onset was significantly decreased in patients carrying the TSHR D727E GC+GG genotype, compared with those carrying the CC genotype $(\mathrm{P}=0.009$; Table 5 and Figure 1).

Table 5. Comparison of age at disease onset in hyperthyroid patients on the basis of the genotyping results.

\begin{tabular}{l|l|c}
\hline & Hyperthyroid patients & P value \\
\hline Age (means + SD) in CC genotype & Age (means + SD) in GC genotype & $0.009^{\mathrm{a}}$ \\
\hline $42.96 \pm 11.99$ & $35.25 \pm 12.03$ & \\
\hline
\end{tabular}

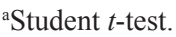

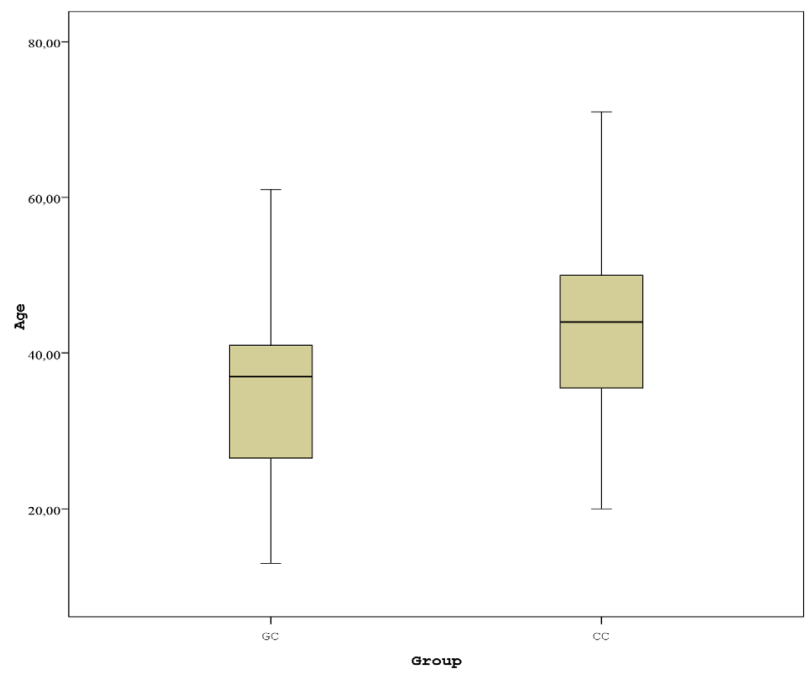

Figure 1. Comparison of age at disease onset between patients with/without the D727E polymorphism in the hyperthyroid patient group. CC represents the D727 (wild-type) genotype; GC represents the heterozygous D727E genotype.

Genetics and Molecular Research 15 (3): gmr.15038504 
Serum TSH levels of the patients were not compared between CC and GC genotypes because of a considerable variability in TSH levels resulting from anti-thyroid medication in the hyperthyroid patient group. In contrast, serum TSH levels were higher in the control subjects carrying the CC genotype $(1.76 \pm 0.84 \mathrm{mIU} / \mathrm{mL})$ compared with those carrying the GC genotype (1.26 \pm 0.49$)$. This result was close to statistical significance (P $=0.053$; Table 6 and Figure 2).

Table 6. Comparison of thyroid-stimulating hormone (TSH) levels in controls on the basis of the genotyping
results.
\begin{tabular}{l|c|c|c|c|c}
\hline & $T S H R$ D 727 CC genotype & TSHR D 727 GC genotype & P value \\
\cline { 2 - 6 } & Means \pm SD & Median & Means \pm SD & Median & \\
\hline TSH level $(\mu \mathrm{IU} / \mathrm{mL})$ in controls & $1.74 \pm 0.84$ & 1.60 & $1.26 \pm 0.49$ & 1.21 & $0.053^{\mathrm{a}}$ \\
\hline
\end{tabular}

${ }^{\mathrm{a}}$ Mann-Whitney U-test.

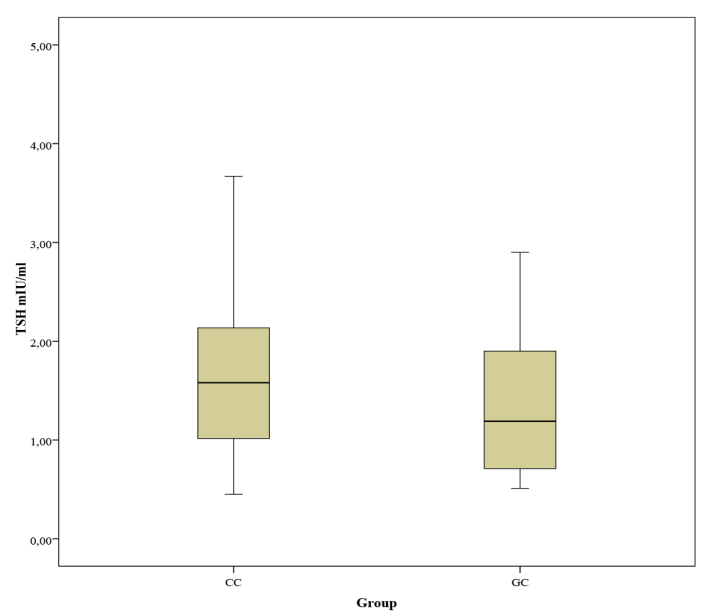

Figure 2. Comparison of thyroid-stimulating hormone (TSH) levels $(\mu \mathrm{IU} / \mathrm{mL})$ in the control subjects with/without the D727E polymorphism. CC represents the D727 (wild-type) genotype; GC represents the heterozygous D727E genotype.

The effect of cigarette smoking on thyroid volume was considered. To evaluate the effects of smoking on thyroid volume, the patients carrying a polymorphic allele were excluded from the statistical analysis. The thyroid volume was higher in smokers than in non-smokers in the hyperthyroid patient group, although the difference was not statistically significant $(77.87$ vs $55.26 \mathrm{~mL} ; \mathrm{P}=0.254)$. Similarly, to determine the effects of the TSHR D727E polymorphism on thyroid volume, the patients with a smoking habit were excluded from the statistical analysis. In the hyperthyroid groups, the thyroid volume of patients with the TSHR D727E GC+GG variant was higher than in the patients with the wild-type genotype. Surprisingly, the result was close to statistical significance (91.23 vs $55.26 \mathrm{~mL} ; \mathrm{P}=0.077$; Table 7).

Genetics and Molecular Research 15 (3): gmr.15038504 
Table 7. Comparison of thyroid volume in patients depending on smoking habit and genotyping results.

\begin{tabular}{|c|c|c|c|c|}
\hline & \multicolumn{4}{|c|}{ Thyroid volume } \\
\hline & $\begin{array}{l}\text { All patients with wild-type }(\mathrm{CC}) \text { genotype } \\
\text { Thyroid volume }(\mathrm{mL}) \text { means }+\mathrm{SD}\end{array}$ & $P$ value & $\begin{array}{l}\text { Hyperthyroid patients with wild-type (CC) genotype } \\
\text { Thyroid volume }(\mathrm{mL}) \text { means }+\mathrm{SD}\end{array}$ & P value \\
\hline Smokers & $82.37 \pm 72.10$ & $0.517^{\mathrm{a}}$ & $77.87 \pm 77.27$ & $0.254^{\mathrm{a}}$ \\
\hline Non-smokers & $70.70 \pm 61.70$ & & $55.26 \pm 50.86$ & \\
\hline & All patients without smoking habits & & Hyperthyroid patients without smoking habits & \\
\hline CC genotype & $70.71 \pm 61.73$ & $0.284^{\mathrm{a}}$ & $55.26 \pm 50.86$ & $0.077^{\mathrm{a}}$ \\
\hline GC+GG genotype & $88.06 \pm 61.73$ & & $91.23 \pm 70.76$ & \\
\hline
\end{tabular}

astudent $t$-test.

\section{DISCUSSION}

Nodular thyroid disease, which encompasses solitary or multiple nodules, is a heterogeneous disorder. Primary and secondary factors are involved in the etiology of nodular goiter (Studer et al., 1989). Today, although the important role of iodine deficiency and the growth-promoting contribution of TSH are still recognized, nodular goiter is now considered a consequence of an inherited propensity for the thyroid to develop nodules with age (Knobel, 2015).

Hereditary transmission in nodular goiter is complex. In addition, the occurrence of nodular goiter during adolescence and the association with a clear familial history, even in conditions of normal dietary iodine intake, are highly indicative of genetic susceptibility (Tajtáková et al., 1998; Langer et al., 1999). This hypothesis is also supported by a study on twins (Brix et al., 1999). In addition to major candidate genes such as TG, TPO, NIS, the pendrin gene (SLC26A4), and TSHR, genome-wide linkage analysis has identified some candidate loci, such as MNG1 on chromosome 14q31, MNG2 on xp22, and other candidate loci on chromosomes 2q, 3p, 7q, and 8p in the development of nodular goiter (Bignell et al., 1997; Neumann et al., 1999; Capon et al., 2000; Bayer et al., 2004). Moreover, linkage studies can miss possible weak genetic defects predisposing to nodular goiter. Therefore, it is not negligible that these weak genetic variations on different genome regions might lead to goiter predisposition. Furthermore, the widely accepted risk factors such as iodine deficiency, smoking, old age, and female gender are likely to interact with and/or trigger genetic susceptibility (Krohn et al., 2005).

Germline polymorphisms in the, TSHR gene may be weak genetic factors that increase genetic susceptibility to the development of goiter. The TSHR D727E polymorphism has been identified as a cause of Graves' disease (Chistiakov et al., 2002; Chistiakov, 2003), Graves' orbitopathy (Jurecka-Lubieniecka et al., 2014), and TMNG (Gabriel et al., 1999; Mühlberg et al., 2000; Sykiotis et al., 2003; Hansen et al., 2007; Tug et al., 2012; Bayram et al., 2013) in different populations over the past few years. Although an in vitro study showed that the TSHR D727E variant caused an increased cAMP response of the receptor to TSH (Gabriel et al., 1999), other studies could not confirm this result (Ban et al., 2002; Sykiotis et al., 2003). Indeed, the results of population-based studies regarding the effect of the TSHR D727E variant are also conflicting.

D727E, a polymorphism of TSHR within the carboxy terminal intracellular tail, was first described by Gabriel et al. (1999) who suggested that it was associated with TMNG and its presence was an important predisposing gene. In their study, 8 of 24 patients (33\%) were heterozygous for the TSHR D727E polymorphism; 9.6\% of normal individuals were heterozygous for the same polymorphism $(\mathrm{P}=0.019)$ (Gabriel et al., 1999). Several studies

Genetics and Molecular Research 15 (3): gmr.15038504 
have documented the presence of the heterozygote polymorphism of TSHR D727E in nodular goiter with varying frequencies ranging from 13 to $46.3 \%$ since 1999 . The genotype distribution and allele frequency of the same polymorphism were reported as $9.6-33 \%$ in normal healthy individuals (Gabriel et al., 1999; Mühlberg et al., 2000; Sykiotis et al., 2003; Hansen et al., 2007; Tug et al., 2012; Bayram et al., 2013).

The first study on the relationship between the TSHR D727E polymorphism and nodular goiter was reported in a Turkish population by Tug et al. (2012), who did not find any association between TSHR D727E and MNG occurrence (9/31 patients with GC (29.03\%); $6 / 30$ controls $(20 \%)$; no GG genotype detected in both groups; $\mathrm{P}=0.4)$. However, their findings are not reliable because of the small sample size of the patients and controls (Tug et al., 2012). Another study from Turkey by Bayram et al. (2013) reported that the D727E polymorphism $\mathrm{G}$ allele frequency and the $\mathrm{CG}$ and GG genotypes were significantly more frequent in patients with MNG. Although this study had large patient and control groups, the results were surprising in that the D727E polymorphism G allele frequency and the CG and GG genotypes were significantly higher in patients with MNG [139/300 patients with nodular goiter $(46.3 \%) ; 44 / 142$ healthy controls $(33 \%) ; \mathrm{P}<0.05]$. The frequency of the TSHR polymorphism was highest in both the patients and controls in the studies performed to date. Therefore, the current study was planned to resolve this discrepancy in the Turkish population.

In this study, although no significant difference was found in the D727E polymorphism frequencies between the patients with nodular goiter [26/123 patients $(21.1 \%)$ ] and the controls [12/97 patients $(12.4 \%) ; \mathrm{P}=0.107$; Table 2], the frequency of the TSHR polymorphism in the hyperthyroid+subclinical hyperthyroid group (23\%) was significantly higher than in the other groups including the euthyroid patients $(9.1 \%)$ and the healthy controls $(12.4 \% ; \mathrm{P}=0.024)$. Moreover, a statistically significant difference was also found between the hyperthyroid+subclinical hyperthyroid group and the euthyroid subgroup $(\mathrm{P}=$ 0.048). Furthermore, statistical power was much higher between the hyperthyroid+subclinical hyperthyroid patients and control subjects in comparison with the other groups $(\mathrm{P}=0.034$; Table 3). Therefore, the results in this study are not found to be as high as those reported by Bayram et al. (2013) and are more concordant with those reported by Gabriel et al. (1999). Moreover, the prevalence of the homozygous GG genotype was detected as 2/123 (1.6\%) in all the patients, and even the homozygous GG genotype could not be found in the control subjects (Table 2). The GG genotype prevalence was much lower than the study by Bayram et al. (2013) (10\% in patients and 4.9\% in controls).

This study suggests that the TSHR gene D727E polymorphism is not important in the etiopathogenesis of multinodular goiter, but it might play an important role in the pathogenesis of hyperthyroidism, and correspondingly toxic multinodular goiter. The variant receptor might demonstrate altered biological behavior, thereby participating in the pathogenesis of TMNG.

Iodine may have a substantial effect on thyroid growth and goiter in iodine-deficient areas (Krohn et al., 2005). Turkey is an endemic goiter region in which total goiter prevalence was reported to be $31.8 \%$ before mandatory iodization in 2002. Although Turkey is generally known as an iodine-deficient region, there are some iodine-sufficient regions (Gozu et al., 2006). In this study, the prevalence of patients from iodine-deficient regions was significantly higher than in the controls ( 31.7 vs $4.1 \%$; $\mathrm{P}=0.001$; Table 1$)$. This demonstrates that iodine deficiency is the primary reason for the development of nodular goiter in iodine-deficient regions, as described in the literature.

The goitrogenic action of smoking may be related to the goitrogenic effect of

Genetics and Molecular Research 15 (3): gmr.15038504 
thiocyanate (SCN-) and probably other byproducts of smoke. SCN-, which acts mainly by preventing iodine capture, may not be a very important goitrogenic cofactor in iodine-sufficient areas (Pontikides and Krassas, 2002). Although not significant, smoker patients with the wildtype genotype had larger thyroid volumes, contrary to the result reported by Jörn et al. (2008). However, it is intriguing that non-smoker hyperthyroid patients carrying the GC genotype had a larger thyroid volume, a finding that was close to statistical significance $(\mathrm{P}=0.077)$. This result indicates that smoking and/or the TSHR D727E polymorphism might constitute an additive risk factor for the development of TMNG. However, to prove this finding further studies with larger patient populations are needed.

Approximately $41 \%$ of children with thyroid nodules have a family history of thyroid disorders (Guille et al., 2015). Therefore, goiter can develop at an early age if there is a family history of the disorder. In this study, family history seemed additive to the formation of MNG. Prevalence of family history in the patient group was significantly higher compared with the controls (38 vs 22.7\%; $\mathrm{P}=0.015)$. Moreover, age at disease onset may be earlier if there is a family history (36.58 vs 41.48 years; $\mathrm{P}=0.036$; Table 1$)$. Furthermore, it is statistically significant that nodular goiter developed earlier in the patients carrying the GC genotype (35 years) in comparison with the patients carrying the CC genotype (42 years) in the hyperthyroid group ( $\mathrm{P}=0.009$; Table 5). Indeed, the $\mathrm{D} 727 \mathrm{E}$ polymorphism was detected in 9 of 29 patients (31\%) who developed toxic multinodular goiter between the ages of 11 and 18 years in the study by Eszlinger et al. (2014). Thus, the D727E polymorphism might predispose to the development of goiter at an early age.

Although, no significant difference was found in the TSHR D727E polymorphism frequencies between the patients with nodular goiter and the controls in this study, a significantly higher frequency of the D727E polymorphism was observed in the hyperthyroid+subclinical hyperthyroid patient group. Therefore, one may suggest that this polymorphism causes hyperthyroidism, as described in the literature (Gabriel et al., 1999; Mühlberg et al., 2000; Sykiotis et al., 2003; Hansen et al., 2007; Tug et al., 2012; Bayram et al., 2013). Although this variant was not constitutively activating, there was an altered response to TSH associated with increased cAMP generation when compared with that in the wild-type, indicating that it does possess somewhat altered biological behavior with respect to adenylate cyclase activation, thereby participating in the pathogenesis of TMNG. However, more importantly, the TSH level in the healthy controls carrying the $T S H R$ D727E (GC) variant was close to significantly lower (1.26 \pm 0.49$)$, compared with those carrying the TSHR 727D (CC, wild-type) variant in the control subjects $(1.74 \pm 0.84 ; \mathrm{P}=0.053$; Table 6$)$. As a point of fact, it was also demonstrated that the TSHR D727E allele was associated with decreasing TSH levels in 1241 healthy Danish twins, but not associated with thyroid size (Hansen et al., 2007).

In healthy subjects, thyroid hormone bioactivity varies with inter-individual variability, which is caused by both genetic and environmental factors (Peeters et al., 2006). Genetic factors account for about $65 \%$ of the variation in serum TSH, fT4, and fT3 levels (Andersen et al., 2002; Hansen et al., 2004). Therefore, the polymorphism we studied might also be associated with a decreased level of TSH in healthy controls. Therefore, control subjects with the D727E polymorphism should be followed-up regularly for development of nodular goiter and hyperthyroidism, even though their hormones and thyroid texture are normal.

In conclusion, our findings indicate that the TSHR D727E polymorphism is significantly associated with TMNG in Turkish patients. However, the results of the studies on this subject are still controversial because the development of MNG is multifactorial. More importantly,

Genetics and Molecular Research 15 (3): gmr.15038504 
it is clear that TMNG might develop earlier in patients with the D727E polymorphism. Thus, these patients are more susceptible to TMNG. Furthermore, the mean TSH levels of the control subjects carrying the TSHR D727E polymorphism were close to being significantly lower, although all of their thyroid parameters were normal. Therefore, further case-control studies with larger populations are required to confirm these findings.

\section{Conflicts of interest}

The authors declare no conflict of interest.

\section{REFERENCES}

Andersen S, Pedersen KM, Bruun NH and Laurberg P (2002). Narrow individual variations in serum T(4) and T(3) in normal subjects: a clue to the understanding of subclinical thyroid disease. J. Clin. Endocrinol. Metab. 87: 10681072. http://dx.doi.org/10.1210/jcem.87.3.8165

Bahn RS and Castro MR (2011). Approach to the patient with nontoxic multinodular goiter. J. Clin. Endocrinol. Metab. 96: 1202-1212. http://dx.doi.org/10.1210/jc.2010-2583

Ban Y, Greenberg DA, Concepcion ES and Tomer Y (2002). A germline single nucleotide polymorphism at the intracellular domain of the human thyrotropin receptor does not have a major effect on the development of Graves' disease. Thyroid 12: 1079-1083. http://dx.doi.org/10.1089/105072502321085171

Bayer Y, Neumann S, Meyer B, Rüschendorf F, et al. (2004). Genome-wide linkage analysis reveals evidence for four new susceptibility loci for familial euthyroid goiter. J. Clin. Endocrinol. Metab. 89: 4044-4052. http://dx.doi.org/10.1210/ jc. 2003-032096

Bayram B, Sonmez R, Bozari S, Onlu H, et al. (2013). The association between development and progression of multinodular goiter and thyroid-stimulating hormone receptor gene D727E and P52T polymorphisms. Genet. Test. Mol. Biomarkers 17: 109-114.http://dx.doi.org/10.1089/gtmb.2012.0263

Bignell GR, Canzian F, Shayeghi M, Stark M, et al. (1997). Familial nontoxic multinodular thyroid goiter locus maps to chromosome 14q but does not account for familial nonmedullary thyroid cancer. Am. J. Hum. Genet. 61: 1123-1130. http://dx.doi.org/10.1086/301610

Biondi B, Palmieri EA, Klain M, Schlumberger M, et al. (2005). Subclinical hyperthyroidism: clinical features and treatment options. Eur. J. Endocrinol. 152: 1-9. http://dx.doi.org/10.1530/eje.1.01809

Brix TH, Kyvik KO and Hegedüs L (1999). Major role of genes in the etiology of simple goiter in females: a populationbased twin study. J. Clin. Endocrinol. Metab. 84: 3071-3075.

Capon F, Tacconelli A, Giardina E, Sciacchitano S, et al. (2000). Mapping a dominant form of multinodular goiter to chromosome Xp22. Am. J. Hum. Genet. 67: 1004-1007.http://dx.doi.org/10.1086/303095

Chistiakov DA (2003). Thyroid-stimulating hormone receptor and its role in Graves' disease. Mol. Genet. Metab. 80: 377 388. http://dx.doi.org/10.1016/j.ymgme.2003.09.001

Chistiakov DA, Savost'anov KV, Turakulov RI, Petunina N, et al. (2002). Further studies of genetic susceptibility to Graves' disease in a Russian population. Med. Sci. Monit. 8: CR180-CR184.

Duprez L, Parma J, Van Sande J, Rodien P, et al. (1998). TSH receptor mutations and thyroid disease. Trends Endocrinol. Metab. 9: 133-140.http://dx.doi.org/10.1016/S1043-2760(98)00036-8

Eszlinger M, Niedziela M, Typlt E, Jaeschke H, et al. (2014). Somatic mutations in 33 benign and malignant hot thyroid nodules in children and adolescents. Mol. Cell. Endocrinol. 393: 39-45.http://dx.doi.org/10.1016/j.mce.2014.05.023

Gabriel EM, Bergert ER, Grant CS, van Heerden JA, et al. (1999). Germline polymorphism of codon 727 of human thyroid-stimulating hormone receptor is associated with toxic multinodular goiter. J. Clin. Endocrinol. Metab. 84: 3328-3335.

Gozu H, Eszlinger M, Bircan R and Paschke R (2009). Hyperthyroidism due to thyroid autonomy. In: Encyclopedia of Molecular Mechanism of Disease (Lang F, ed.). Springer, Berlin-Heidelberg, 943-945.

Gozu HI, Bircan R, Krohn K, Müller S, et al. (2006). Similar prevalence of somatic TSH receptor and Gsalpha mutations in toxic thyroid nodules in geographical regions with different iodine supply in Turkey. Eur. J. Endocrinol. 155: 535545.http://dx.doi.org/10.1530/eje.1.02253

Greig WR, Boyle JA, Duncan A, Nicol J, et al. (1967). Genetic and non-genetic factors in simple goitre formation: evidence from a twin study. Q. J. Med. 36: 175-188.

Genetics and Molecular Research 15 (3): gmr.15038504 
Guille JT, Opoku-Boateng A, Thibeault SL and Chen H (2015). Evaluation and management of the pediatric thyroid nodule. Oncologist 20: 19-27. http://dx.doi.org/10.1634/theoncologist.2014-0115

Hansen PS, Brix TH, Sørensen TI, Kyvik KO, et al. (2004). Major genetic influence on the regulation of the pituitarythyroid axis: a study of healthy Danish twins. J. Clin. Endocrinol. Metab. 89: 1181-1187. http://dx.doi.org/10.1210/ jc.2003-031641

Hansen PS, van der Deure WM, Peeters RP, Iachine I, et al. (2007). The impact of a TSH receptor gene polymorphism on thyroid-related phenotypes in a healthy Danish twin population. Clin. Endocrinol. 66: 827-832. http://dx.doi. org/10.1111/j.1365-2265.2007.02820.x

Jörn J, Miehle K, Schmidt C, Wicht J, et al. (2008). Cigarette smoking but not the TSHR germline polymorphism D727E is associated with toxic multinodular goitre (TMNG) and the thyroid volume. Endocrine Abstracts 16: 700.

Jurecka-Lubieniecka B, Ploski R, Kula D, Szymanski K, et al. (2014). Association between polymorphisms in the TSHR gene and Graves' orbitopathy. PLoS One 9: e102653.http://dx.doi.org/10.1371/journal.pone.0102653

Knobel M (2015). Etiopathology, clinical features, and treatment of diffuse and multinodular nontoxic goiters. $J$. Endocrinol. Invest.

Krohn K, Führer D, Bayer Y, Eszlinger M, et al. (2005). Molecular pathogenesis of euthyroid and toxic multinodular goiter. Endocr. Rev. 26: 504-524. http://dx.doi.org/10.1210/er.2004-0005

Langer P, Tajtáková M, Bohov P and Klimes I (1999). Possible role of genetic factors in thyroid growth rate and in the assessment of upper limit of normal thyroid volume in iodine-replete adolescents. Thyroid 9: 557-562. http://dx.doi. org/10.1089/thy.1999.9.557

Malamos B, Koutras DA, Kostamis P, Rigopoulos GA, et al. (1967). Endemic goitre in Greece: a study of 379 twin pairs. J. Med. Genet. 4: 16-18. http://dx.doi.org/10.1136/jmg.4.1.16

Mühlberg T, Herrmann K, Joba W, Kirchberger M, et al. (2000). Lack of association of nonautoimmune hyperfunctioning thyroid disorders and a germline polymorphism of codon 727 of the human thyrotropin receptor in a European Caucasian population. J. Clin. Endocrinol. Metab. 85: 2640-2643.

Neumann S, Willgerodt H, Ackermann F, Reske A, et al. (1999). Linkage of familial euthyroid goiter to the multinodular goiter-1 locus and exclusion of the candidate genes thyroglobulin, thyroperoxidase, and Na+/I- symporter. J. Clin. Endocrinol. Metab. 84: 3750-3756.

Paschke R and Ludgate M (1997). The thyrotropin receptor in thyroid diseases. N. Engl. J. Med. 337: 1675-1681. http:// dx.doi.org/10.1056/NEJM199712043372307

Peeters RP, van der Deure WM and Visser TJ (2006). Genetic variation in thyroid hormone pathway genes; polymorphisms in the TSH receptor and the iodothyronine deiodinases. Eur. J. Endocrinol. 155: 655-662.http://dx.doi.org/10.1530/ eje. 1.02279

Pontikides N and Krassas GE (2002). Influence of cigarette smoking on thyroid function, goiter formation and autoimmune thyroid disorders. Hormones (Athens) 1: 91-98.http://dx.doi.org/10.14310/horm.2002.1156

Porcellini A, Fenzi G and Avvedimento EV (1997). Mutations of thyrotropin receptor gene. J. Mol. Med. 75: 567-575. http://dx.doi.org/10.1007/s001090050141

Studer H, Peter HJ and Gerber H (1989). Natural heterogeneity of thyroid cells: the basis for understanding thyroid function and nodular goiter growth. Endocr. Rev. 10: 125-135. http://dx.doi.org/10.1210/edrv-10-2-125

Sykiotis GP, Neumann S, Georgopoulos NA, Sgourou A, et al. (2003). Functional significance of the thyrotropin receptor germline polymorphism D727E. Biochem. Biophys. Res. Commun. 301: 1051-1056. http://dx.doi.org/10.1016/ S0006-291X(03)00071-8

Tonacchera M and Pinchera A (2000). Thyrotropin receptor polymorphisms and thyroid diseases. J. Clin. Endocrinol. Metab. 85: 2637-2639. http://dx.doi.org/10.1210/jcem.85.8.6801

Tug E, Sengül N, Aydin H and Yilmaz E (2012). The impact of the D727E polymorphism has no significant role in multi nodular goiter. Balkan J. Med. Genet. 15: 67-72.http://dx.doi.org/10.2478/bjmg-2013-0009

Tajtáková M, Langer P, Gonsorcíková V, Bohov, et al. (1998). Recognition of a subgroup of adolescents with rapidly growing thyroids under iodine-replete conditions: seven year follow-up. Eur. J. Endocrinol. 138: 674-680. http:// dx.doi.org/10.1530/eje. 0.1380674

Genetics and Molecular Research 15 (3): gmr.15038504 